\title{
Performance of RR soybean submitted to postemergence application of glyphosate with a foliar elicitor product
}

\section{Desempenho da soja RR submetida a aplicação de glifosato associado a produto elicitor foliar em pós-emergência}

\author{
Jamil Constantin' (1) (https://orcid.org/0000-0001-6610-699X) \\ Guilherme Braga Pereira Braz 2* (1) (https://orcid.org/0000-0002-0396-7140) \\ Rubem Silvério de Oliveira Júnior ${ }^{1}$ (1) (https://orcid.org/0000-0002-5222-8010) \\ Christiano Lima Lobo de Andrade ${ }^{2}$ (1) (https://orcid.org/0000-0002-6743-3666) \\ Bruno César Silva Pereira ${ }^{2}$ (1) (https://orcid.org/0000-0002-4708-143X) \\ Fellipe Goulart Machado' (1) (https://orcid.org/0000-0003-1565-988X)
}

\begin{abstract}
With the advent of glyphosate-resistant soybean, postemergence applications of the herbicide have become routine. In this way, problems related to the selectivity of glyphosate have been shown to be increasingly intense, due to the use of increased dosages and applications of the herbicide at unrecommended moments. In order to evaluate the agronomic performance of soybean plants subjected to the postemergence application of glyphosate - both in isolation and together with $\mathrm{Crop}^{+}-$at different stages and dosage levels, a randomized block design experiment was carried out with two adjacent checks and four repetitions. The treatments consisted of: glyphosate (1296 g.ha-1); glyphosate $+\operatorname{Crop}^{+}\left(1296+0.25\right.$ g or L $\left.\cdot h^{-1}{ }^{-1}\right)$ glyphosate + Crop $^{+}$ $\left(1296+0.5 \mathrm{~g}\right.$ or L.ha- $\left.{ }^{-1}\right)$; glyphosate $\left(2592 \mathrm{~g} \cdot \mathrm{ha}^{-1}\right)$; glyphosate + $\mathrm{Crop}^{+}\left(2592+0.25 \mathrm{~g}\right.$ or L·ha $\left.{ }^{-1}\right)$; glyphosate $+\operatorname{Crop}^{+}(2592+0.5 \mathrm{~g}$ or L.ha $\left.{ }^{-1}\right) ; 2 \times$ glyphosate $\left(2 \times 1296 \mathrm{~g} \cdot \mathrm{ha}^{-1}\right) ; 2 \times$ glyphosate Crop Cr $^{+}$ $\left(2 \times 1296+0.25 \mathrm{~g}\right.$ or L $\left.\cdot \mathrm{ha}^{-1}\right) ; 2 \times$ glyphosate $^{-\mathrm{Crop}^{+}}(2 \times 1296$ $+0.5 \mathrm{~g}$ or L$\left.\cdot \mathrm{ha}^{-1}\right)$ and $\mathrm{Crop}^{+}\left(0.5 \mathrm{~g} \cdot \mathrm{ha}^{-1}\right)$. The phytotoxicity, soil plant analysis development (SPAD) index, height, stand, mass of 100 grains, and yield of the soybean plants were evaluated. The use of $\mathrm{Crop}^{+}$on soybean plants led to an increase in the SPAD index; the use of $\mathrm{Crop}^{+}$in association with glyphosate made possible the attenuation of visible symptoms of damage, preventing reductions in crop yield.
\end{abstract}

KEYWORDS: biostimulant; phytotoxicity; EPSPS inhibitor; yield.
RESUMO: Com o advento da soja resistente ao glifosato, aplicaçôes em pós-emergência da cultura tornaram-se corriqueiras. Dessa forma, problemas relacionados à seletividade desse herbicida mostraram-se cada vez mais intensos, devido ao aumento da dose utilizada e à aplicaçáo em momentos náo recomendados. Para avaliar o desempenho agronômico da soja submetida à aplicação de glifosato isolado em pós-emergência e em associação ao Crop ${ }^{+}$ em diferentes estádios e doses, um experimento foi realizado em delineamento de blocos ao acaso, em esquema de testemunhas duplas adjacentes, adotando-se quatro repetiçóes. Os tratamentos foram constituídos por: glifosato $\left(1296 \mathrm{~g} \cdot \mathrm{ha}^{-1}\right)$; glifosato $+\mathrm{Crop}^{+}(1296$ $+0,25 \mathrm{~g}$ ou L$\left.\cdot \mathrm{ha}^{-1}\right)$; glifosato $+\operatorname{Crop}^{+}\left(1296+0,5 \mathrm{~g} \mathrm{ou} \mathrm{L} \cdot \mathrm{ha}^{-1}\right)$; glifosato $\left(2592 \mathrm{~g} \cdot \mathrm{ha}^{-1}\right)$; glifosato $+\operatorname{Crop}^{+}\left(2592+0,25 \mathrm{~g} \mathrm{ou} \mathrm{L} \cdot \mathrm{ha}^{-1}\right)$; glifosato $+\operatorname{Crop}^{+}\left(2592+0,5\right.$ g ou L.ha $\left.{ }^{-1}\right) ; 2 \times$ glifosato $\left(2 \times 1296\right.$ g.ha $\left.{ }^{-1}\right)$; $2 \times$ glifosato + Crop $^{+}\left(2 \times 1296+0,25\right.$ g ou L $\left.\cdot h^{-1}\right) ; 2 \times$ glifosato + $\operatorname{Crop}^{+}\left(2 \times 1296+0,5 \mathrm{~g} \mathrm{ou} \mathrm{L} \cdot \mathrm{ha}^{-1}\right) \mathrm{eCrop}^{+}\left(0,5 \mathrm{~g} \cdot \mathrm{ha}^{-1}\right)$. Foram avaliados fitointoxicação das plantas de soja, índice SPAD (soil plant analysis development), altura, estande, massa de cem grãos e produtividade. Nos resultados, a utilização de $\mathrm{Crop}^{+}$em plantas de soja proporcionou o aumento no índice SPAD e, quando o $\mathrm{Crop}^{+}$foi associado ao glifosato, possibilitou a atenuação dos sintomas visuais de injúrias, prevenindo reduçôes na produtividade da cultura.

PALAVRAS-CHAVE: bioestimulante; fitointoxicação; inibidor da EPSPs; produtividade.

\footnotetext{
'Universidade Estadual de Maringá - Departamento de Agronomia - Maringá (PR), Brazil.

${ }^{2}$ Universidade de Rio Verde - Faculdade de Agronomia - Rio Verde (GO), Brazil.

*Corresponding author: guilhermebrag@gmail.com

Received on: 6/18/2019. Accepted on: 9/27/2020
} 


\section{INTRODUCTION}

The advent of soybean cultivars with glyphosate tolerance (RR and later IPRO) brought a series of benefits for the producer, notable among these is the decreased cost of dealing with weeds (when comparing the price of glyphosate in relation to other products used in conventional soybean cultivation), an increased range of control (due to the effectiveness of glyphosate towards mono- and dicotyledon species), and the nonoccurrence of carryover to crops planted subsequent to the soy because of the absence of residual herbicidal activity (CONSTANTIN et al., 2016; GREEN, 2018). Despite the benefits brought about by this technology, the linear increase in the adoption of glyphosate-resistant soybean has brought visible bottlenecks in the system of production that have used these materials.

The extensive adoption of glyphosate-resistant soybean, as well as other crops that display the same characteristic (corn and cotton), made it so that there was intensive pressure in the selection of biotypes of glyphosate-resistant weeds, given that species such as sourgrass and hairy fleabane constitute some of the main bottlenecks in Brazilian production (OVEJERO et al., 2017; HEAP, 2019). To convey the scope of the losses caused by these weeds, it is estimated that the average annual cost of resistance in Brazil, taking into consideration only the system of soybean production, is close to $\mathrm{R} \$ 5$ billion ( $\$ 1$ billion USD) per year. This amount could reach as high as $\mathrm{R} \$ 9$ billion when including losses in crop yield due to the interference of the weeds in question (ADEGAS et al., 2017).

The scope of the damage caused by the occurrence of resistant weeds is enormous and causes serious concern, but another situation in which reductions in soybean yield have been observed - and at times neglected - is related to the real selectivity that glyphosate demonstrates for cultivars that contain traits conferring tolerance to the herbicide. In the literature there are a series of studies that report the deleterious effect that glyphosate has on parameters of growth and soybean production (ZOBIOLE et al., 2011; CONSTANTIN et al., 2016). The negative effects that can be seen after the application of glyphosate are related to micronutrient deficiency, lower photosynthetic efficiency, greater water absorption by the plants in order to metabolize the herbicide, and lower soybean nodulation (SERRA et al., 2011; ZOBIOLE et al., 2010a; 2010b; 2012; KRENCHINSKI et al., 2017).

In order to mitigate the negative effects caused by glyphosate in resistant soybean cultivars, one of the possibilities that has been amply researched relates to the use of products that provide the plants with improved growth. In this context, the products that have been most widely used are foliar fertilizers, biostimulants, and amino acids (CONSTANTIN et al., 2016; MATYSIAK et al., 2018; MACHADO et al., 2018). Each of these products presents a specific mechanism that aims to attenuate the effects resulting from the application of glyphosate. For example, in the case of foliar fertilizers, the intent is to exogenously supplement the lack of micronutrients, which can come about by virtue of the glyphosate's chelating action.

Biostimulants and amino acids provide greater vegetative development to the treated plants, which results in growth both aboveground and in the root system (SANTOS et al., 2014). As previously mentioned, soybean plants that are subjected to glyphosate application show changes in water use efficiency, increasing the water intake necessary for the process of metabolizing the herbicide to occur (ZOBIOLE et al., 2010a). In this context, plants that are strong and have an abundant root system possess a greater capacity to exploit the soil, which in turn makes it possible for them to access a larger volume of water.

In this context, the objective of this study was to evaluate the agronomic performance of soybean plants subjected to postemergence application of glyphosate - both in isolation and together with the foliar elicitor $\mathrm{Crop}^{+}$, applied at different stages and doses.

\section{MATERIAL AND METHODS}

The experiment was established in an experimental station located in the municipality of Rio Verde, state of Goiás, Brazil, from 11/22/2018 to 03/04/2019. This experiment was specifically installed at latitude $17^{\circ} 46^{\prime} 52.03^{\prime \prime} \mathrm{S}$ and longitude $50^{\circ} 58^{\prime} 13.46^{\prime \prime} \mathrm{W}$, at an altitude of $789 \mathrm{~m}$.

According to the Köppen classification system, the climate of the municipality of Rio Verde is of Type Aw or "tropical with a dry season". This climate is characterized by rains that are more intense in the summer than in the winter. Figure 1 contains climate data related to the average air temperature and precipitation during the period of experiment conduction.

Prior to the experiment installation, soil sampling was performed at a depth of 0 to $20 \mathrm{~cm}$, which revealed the following physiochemical properties: $\mathrm{pH}$ in $\mathrm{CaCl}_{2}$ of $4.87,5.15 \mathrm{cmol}_{\mathrm{c}}$ of $\mathrm{H}^{+}+\mathrm{Al}^{+3} \cdot \mathrm{dm}^{-3}$ of soil, $4.28 \mathrm{cmol}_{c} \cdot \mathrm{dm}^{-3}$ of Ca $\mathrm{Ca}^{+2}, 1.09 \mathrm{cmol}_{\mathrm{c}} \cdot \mathrm{dm}^{-3}$ of $\mathrm{Mg}^{+2}, 0.59 \mathrm{cmol}_{\mathrm{c}} \cdot \mathrm{dm}^{-3}$ of $\mathrm{K}^{+}, 3.08 \mathrm{mg} \cdot \mathrm{dm}^{-3}$ of P; $15.35 \mathrm{~g} \cdot \mathrm{dm}^{-3}$ of C; $49.5 \%$ sand, $5 \%$ silt, and $45.5 \%$ clay (clayey texture).

Prior to seeding, the area was desiccated through two applications of herbicides. The first occurred twenty days prior to seeding $(10 / 31 / 2018)$ with the application of a mixture of glyphosate $+2.4-\mathrm{D}$ amine $\left(1620+483.6 \mathrm{~g} \cdot \mathrm{ha}^{-1}\right)$. The second occurred on the day of seeding (11/20/2018), with the application of the herbicide paraquat $\left(400 \mathrm{~g} \cdot \mathrm{ha}^{-1}\right)$ with the addition of an adhesive spreader (Agral $-0.2 \% \mathrm{v} \cdot \mathrm{v}^{-1}$ ).

Seeding occurred on 11/20/2018 in a no-tillage system, with a spacing of $0.45 \mathrm{~m}$ interrows. Eighteen seeds of the soybean cultivar FLX IPRO, part of BRASMAX, were distributed per linear meter. This cultivar possesses the habit of undetermined growth, maturation group 6.6, a demonstrated early cycle, and good yield stability (BRASMAX, 2019). Seeds were treated with Rocks ( $350 \mathrm{~mL}$ for each $100 \mathrm{~kg}$ of seed), Maxim 


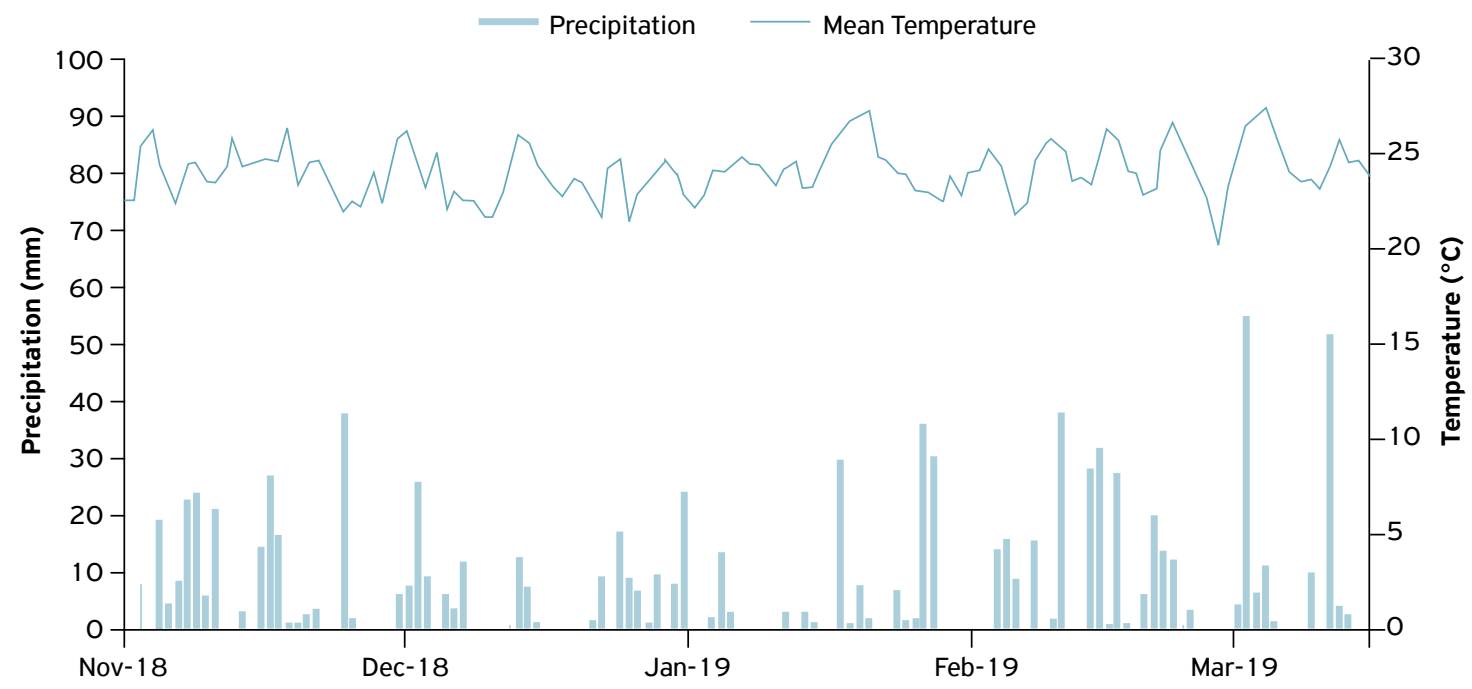

Source: INMET - National Institute of Meteorology - Rio Verde - GO.

Figure 1. Average temperature and precipitation observed during the period in which the experiment was conducted with soybean plants subjected to the postemergent application of glyphosate in different doses and stages and in conjunction with Crop'. Rio Verde (Goiás), 2018-2019.

Advanced (100 mL for each $100 \mathrm{~kg}$ of seed), Quimifol Soja Co-Mo (100 mL for each $100 \mathrm{~kg}$ of seed), and the inoculant Nitragin (seed). The fertilization of the crop occurred at the time of seeding with $170 \mathrm{~kg} \cdot \mathrm{ha}^{-1}$ of MAP. The emergence of the seedlings occurred on 11/25/2018.

The experiment utilized a randomized block design, with double controls and four replications. In this arrangement, each treatment possesses two adjacent checks, which were utilized to compare the values obtained for each treatment. The adoption of this experimental design allows for the comparison of herbicide treatments with the controls placed within the same plot. This, consequently, minimizes variability of the area and experimental error, which is fundamental for experiments that evaluate the selectivity of herbicides.

Table 1 shows the treatments that were evaluated as part of the present study, together with their respective doses and stages of application. The experimental units were composed of five seeded rows, with a spacing of $0.45 \mathrm{~m}$ and length of $5.0 \mathrm{~m}\left(11.25 \mathrm{~m}^{2}\right)$. The area from which evaluations were drawn was limited to the three center rows of the experimental unit and excluded $0.5 \mathrm{~m}$ on each end.

During the growth of soybean, all farming practices - including pest and disease control - were carried out in accordance with recommended practices, without allowing said practices to influence crop growth (EMBRAPA, 2010). All maintenance-related applications were done with a trailed sprayer, with a volume of applied slurry equivalent to $200 \mathrm{~L} \cdot \mathrm{ha}^{-1}$. All experimental units were weeded over the course of the soybean growth, with the intent of eliminating the effect of interference from weeds on the crop, leaving the plants exposed to only the effect of the herbicidal treatments.
Table 1. Treatments evaluated in the experiment with soybean plants subjected to the post-emergent application of glyphosate in conjunction with a foliar elicitor product. Rio Verde (Goiás), 2018-2019.

\begin{tabular}{|c|c|c|}
\hline Treatments & $\begin{array}{c}\text { Dose } \\
\left(\mathrm{g} \text { or } L \cdot h \mathrm{a}^{-1}\right)\end{array}$ & $\begin{array}{c}\text { Stage of } \\
\text { application }\end{array}$ \\
\hline Glyphosate & 1296 & V5 \\
\hline Glyphosate + Crop ${ }^{+}$ & $1296+0.25$ & V5 \\
\hline Glyphosate + Crop ${ }^{+}$ & $1296+0.5$ & V5 \\
\hline Glyphosate & 2592 & V5 \\
\hline Glyphosate + Crop ${ }^{+}$ & $2592+0.25$ & V5 \\
\hline Glyphosate + Crop ${ }^{+}$ & $2592+0.5$ & V5 \\
\hline $2 \times$ glyphosate & $2 \times 1296$ & V3-V4 / V5-V6 \\
\hline $2 \times$ glyphosate + Crop $^{+}$ & $\begin{array}{c}2 \times 1296+ \\
0.25\end{array}$ & V3-V4 / V5-V6 \\
\hline $2 \times$ glyphosate $+\mathrm{Cro}^{\mathrm{p}+}$ & $\begin{array}{c}2 \times 1296+ \\
0.5\end{array}$ & V3-V4 / V5-V6 \\
\hline Crop $^{+}$ & 0.5 & V5 \\
\hline
\end{tabular}

"/" = sequential application; "+" = tank mixture. Commercial formula of glyphosate utilized = Roundup Transorb: $648 \mathrm{~g} \cdot \mathrm{L}^{-1}$ of glyphosate, equivalent to $480 \mathrm{~g} \cdot \mathrm{L}^{-1}$ of acid equivalent.

The first application (Application A) occurred on 12/19/18 (8:30 to 9:00 a.m.) for only those treatments designated for sequential application. At the time of application, the soybean plants were in stage V3-V4 and had heights varying between 25 and $30 \mathrm{~cm}$. In addition, the soil was dry, the air temperature was $26.0^{\circ} \mathrm{C}$, the relative air humidity was at $65 \%$, the sky was clear of clouds, and wind speed was $0.5 \mathrm{~km} \cdot \mathrm{h}^{-1}$. The second application (Application B) occurred on 12/24/18 
(8:30 to 9:15 a.m.), and included treatments slated for a single instance of application. The soybean plants were in stage V5 and had average heights between 30 and $35 \mathrm{~cm}$. At the time of application, the soil was moist, the air temperature was $25.0^{\circ} \mathrm{C}$, the relative air humidity was at $70 \%$, the sky was cloudy, and wind speed was $0.8 \mathrm{~km} \cdot \mathrm{h}^{-1}$.

The final application (Application C; $12 / 26 / 18-9: 00$ to 9:20 a.m.) occurred only for treatments slated for sequential application. The soybean plants were in stage V5-V6, with an average height of $40 \mathrm{~cm}$. At the time of application, the soil was moist, the air temperature was $24.0^{\circ} \mathrm{C}$, the relative air humidity was $75 \%$, the sky was clear of clouds, and windspeed was $1.1 \mathrm{~km} \cdot \mathrm{h}^{-1}$. All treatments were performed with a backpack sprayer with constant $\mathrm{CO}_{2}$-based pressure. The sprayer was equipped with a bar containing five nozzles of type XR-110.02, with a pressure of $2.0 \mathrm{kgf} \cdot \mathrm{cm}^{-2}$. These application conditions provided the equivalent of $200 \mathrm{~L} \cdot \mathrm{ha}^{-1}$ of slurry.

The variables that were evaluated included: crop phytotoxicity (on a visual scale from $0-100 \%$, where $0 \%$ signified an absence of symptoms and $100 \%$ signified total plant death) on the 7 th, 14th, 21st, and 35th days after application (Application B). The days upon which phytotoxicity was evaluated were equivalent to 12, 19, 26, and 40 days after Application A and 5, 12, 19, and 32 days after Application C. The soil plant analysis development (SPAD) index was measured with the use of a SPAD-502 device, which evaluated the second three-part compound leaf completely expanded from the top to the base of the soybean plant, with measurement occurring on the central leaflet of the compound leaf. Five plants were sampled per experimental unit for this evaluation, with measurements taken on the 7th, 14th, 21st, and 35th days after application (Application B).

The height of the soybean plants was measured by the distance from the soil level to the insertion of the last three-part leaf compound to have completely expanded from the soybean plant, with a sample of five plants per experimental unit. The crop stand was evaluated by counting the number of plants present in 2 linear meters of area within each experimental unit. Both of the aforementioned measures were taken on the 14th and 35th day after application (Application B), as well as immediately prior to crop harvest.

In addition, an evaluation of the mass of 100 grains occurred at the time of harvest. This evaluation consisted of counting the 100 grains, which were subsequently weighed on a precision scale and had moisture content corrected to $13 \%$. In order to determine crop yield, a manual harvest of all plants present in each experimental unit occurred on 03/04/2019. All of the treatment and control plants in question were subsequently packaged, labeled, weighed, and had moisture content corrected to $13 \%$.

Data analysis was performed with SISVAR software (FERREIRA, 2011). For statistical analysis of the phytotoxicity response variable, the data were subjected to variance analysis by the F-test. Means were compared with the Scott-Knott test, at $5 \%$ probability. Variance analysis was performed upon the remaining variables; subsequently, the outcomes of the herbicide treatments and their respective controls were compared using the F-test at 5\% probability.

\section{RESULTS AND DISCUSSION}

In soybean cultivars with glyphosate tolerance, the occurrence of symptoms of damage is visible after the application of glyphosate (ALONSO et al., 2011; CONSTANTIN et al., 2016). Even with the transgenic insertion of the gene that codifies the EPSPS enzyme (which allows the plant to manifest an enzyme which is not sensitive to the aforementioned active ingredient; (BECKIE; HALL, 2014), the plant is not capable of totally detoxifying glyphosate in certain situations, or there are observable secondary symptoms derived from the herbicide's phytotoxic action, such as the chelating action of glyphosate, leading to symptoms of deficiency in the micronutrients manganese, iron, and zinc (SERRA et al., 2011; ZOBIOLE et al., 2012).

In this regard, evaluation of the phytotoxicity of soybean plants subjected to glyphosate is essential with an aim of evaluating the selectivity that glyphosate shows towards the crop. In this specific study, this evaluation also becomes important to measure the potential attenuation that $\mathrm{Crop}^{+}$shows when applied in conjunction with glyphosate. Generally, the symptoms observed after glyphosate application are characterized by a light yellowing of the leaves. In addition, in some treatments, plants displayed a reduced level of leaf cover, from a visual standpoint. Regardless, it is important to emphasize that the levels of phytotoxicity were low over the course of all evaluations, never surpassing the level of $12 \%$ (Table 2).

At 7 days after application, comparing only treatments that received isolated applications of glyphosate (without $\mathrm{Crop}^{+}$), the plants that demonstrated damage of a greater intensity were those that received larger glyphosate doses, whether through a single application (glyphosate $-2592 \mathrm{~g} \cdot \mathrm{ha}^{-1}$ ) or sequential applications $\left(2 \times\right.$ glyphosate $\left.-1296 / 1296 \mathrm{~g} \cdot \mathrm{ha}^{-1}\right)$. Regarding the treatments consisting of glyphosate and $\mathrm{Crop}^{+}$, greater phytotoxicity values were found in treatments with sequential application of $2 \times$ glyphosate $+\operatorname{Crop}^{+}\left(1296+0.5 \mathrm{~g}\right.$ or L·ha $\left.{ }^{-1}\right)$, single application of glyphosate $+\mathrm{Crop}^{+}\left(1296+0.25 \mathrm{~g}\right.$ or L.ha $\left.{ }^{-1}\right)$, glyphosate + $\operatorname{Crop}^{+}\left(2592+0.25 \mathrm{~g}\right.$ or L$\left.\cdot h a^{-1}\right)$ and glyphosate $+\operatorname{Crop}^{+}(1296$ $+0.5 \mathrm{~g}$ or L.ha- $\left.{ }^{-1}\right)$. It is worth noting that, at 14 days after application, the behavior of the treatments with regard to the response variable phytotoxicity remained similar to those seen during the evaluation made at seven days after application.

In the third evaluation (21 days after application), the greatest damage to soybean plants was reported on plots that received sequential application of glyphosate $(2 \times$ glyphosate - $1296 \mathrm{~g} \cdot \mathrm{ha}^{-1}$ ) (Table 2). It is worth noting that, on this occasion, the treatments that received the same composition 
Table 2. Phytotoxicity of soybean plants subjected to the postemergent application of glyphosate in conjunction with a foliar elicitor product. Rio Verde (Goiás), 2018-2019.

\begin{tabular}{|c|c|c|c|c|c|}
\hline \multirow{2}{*}{ Treatments } & \multirow{2}{*}{ Dose (g or L·ha-1) } & \multicolumn{4}{|c|}{ Phytotoxicity (\%) } \\
\hline & & 7 DAA & 14 DAA & 21 DAA & 35 DAA \\
\hline Glyphosate & 1296 & $1.2 \mathrm{~b}$ & $2.5 \mathrm{~b}$ & $2.5 \mathrm{~d}$ & $0.0 \mathrm{c}$ \\
\hline Glyphosate + Crop ${ }^{+}$ & $1296+0.25$ & $5.0 \mathrm{a}$ & $3.7 \mathrm{~b}$ & $3.2 \mathrm{~d}$ & $2.5 b$ \\
\hline 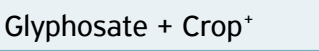 & $1296+0.5$ & $7.5 \mathrm{a}$ & $8.7 \mathrm{a}$ & $9.2 b$ & $5.0 \mathrm{~b}$ \\
\hline Glyphosate & 2592 & $8.2 \mathrm{a}$ & $10.7 \mathrm{a}$ & $6.2 \mathrm{c}$ & $11.2 \mathrm{a}$ \\
\hline Glyphosate + Crop $^{+}$ & $2592+0.25$ & $8.7 \mathrm{a}$ & $6.2 \mathrm{a}$ & $6.5 c$ & $2.5 b$ \\
\hline Glyphosate + Crop ${ }^{+}$ & $2592+0.5$ & $2.5 b$ & $5.0 \mathrm{~b}$ & $5.0 \mathrm{c}$ & $2.5 b$ \\
\hline $2 \times$ glyphosate & $2 \times 1296$ & $8.7 \mathrm{a}$ & $10.7 \mathrm{a}$ & $12.0 \mathrm{a}$ & $10.0 \mathrm{a}$ \\
\hline $2 \times$ glyphosate + Crop $^{+}$ & $2 \times 1296+0.25$ & $2.5 \mathrm{~b}$ & $3.7 \mathrm{~b}$ & $5.0 \mathrm{c}$ & $3.7 \mathrm{~b}$ \\
\hline $2 \times$ glyphosate + Crop $^{+}$ & $2 \times 1296+0.5$ & $8.0 \mathrm{a}$ & $7.5 \mathrm{a}$ & $8.7 \mathrm{~b}$ & $5.0 \mathrm{~b}$ \\
\hline Crop $^{+}$ & 0.5 & $0.0 \mathrm{~b}$ & $0.0 \mathrm{~b}$ & $0.0 \mathrm{e}$ & $0.0 \mathrm{c}$ \\
\hline CV (\%) & & 44.46 & 41.81 & 29.88 & 42.96 \\
\hline
\end{tabular}

* Means followed by different letters are different according to the Scott-Knott test at $5 \%$ probability.

of glyphosate in sequential form, but also had the addition of $\mathrm{Crop}^{+}$(either in a 0.25 or $0.5 \mathrm{~L} \cdot \mathrm{ha}^{-1}$ dose), showed a lower percentage of damage, demonstrating a possible attenuating action of the product on the symptoms caused by the herbicide.

At 35 days after application, the greatest percentage levels of phototoxicity were observed both in treatments with a single application of glyphosate $\left(2592 \mathrm{~g} \cdot \mathrm{ha}^{-1}\right)$ and those with two sequential applications (both of utilized a dose of $1296 \mathrm{~g} \cdot \mathrm{ha}^{-1}$ ). For the remaining treatments, the levels of phototoxicity of the soybean plants were low and did not surpass $5 \%$ (Table 2).

One of the symptoms that was visible after the application of glyphosate to transgenic cultivars of resistant soybean is known as "yellow flashing", which is characterized by intense yellowing of the leaves on treated plants (ZOBIOLE et al., 2010c). Quick evaluation of the coloration of the leaves following the application of glyphosate can aid in identifying possible deleterious effects that the glyphosate has caused in the soybean plants.

One possibility with this intent pertains to the use of the SPAD-502 device, which is a portable measurement device that is used to evaluate the color of green displayed by the plants. This device quantitatively measures the intensity of the green hue of the leaf, measuring transmissions of light at $650 \mathrm{~nm}$, where light absorption by chlorophyll molecules occurs, and at $940 \mathrm{~nm}$, where no such absorption occurs (GIL et al., 2002). Based on these values, the measurement device provides the SPAD index, which has a high correlation with the level of chlorophyll.

At both 7 and 14 days after application, differences in the SPAD index were observed between the treatments and the respective checks for the plants that received sequential application of only glyphosate, in which both applications utilized a dose of $1296 \mathrm{~g} \cdot \mathrm{ha}^{-1}$. This difference was also observed for treatments that utilized a dose of $2592 \mathrm{~g} \cdot \mathrm{ha}^{-1}$ of glyphosate, regardless of whether or not $\mathrm{Crop}^{+}$was added to the application
(Table 3). No differences were observed for treatments that consisted of the sequential application of glyphosate + $\mathrm{Crop}^{+}$, demonstrating that the addition of $\mathrm{Crop}^{+}$to the application prevented observed reductions in the SPAD index.

At 21 days after application, the only treatment demonstrating a difference from its respective checks was the treatment consisting of the application of glyphosate $+\operatorname{Crop}^{+}(2592+$ $0.25 \mathrm{~g}$ or L.ha ${ }^{-1}$; Table 3 ). On that occasion, all of the other treatments manifested similar SPAD index compared to their respective checks, demonstrating that the leaf-yellowing symptom of glyphosate is more intense during the first two weeks following application.

In the final evaluation of the SPAD index, carried out 35 days after application, the soybean plants treated with glyphosate $+\mathrm{Crop}^{+}$in doses of $1296+0.25$ or $2592+0.5 \mathrm{~g}$ or L.ha ${ }^{-1}$ had values lower than those of their respective checks. This behavior demonstrates that, despite the fact that yellowing symptoms are more common in the first weeks following the application of glyphosate, there is the possibility of seeing such yellowing later on. This would indicate that the plant needs, in certain situations, a greater period of time to perform the detoxification from phytotoxicity symptoms promoted by the herbicide. This assertion can be substantiated by studies available in the literature, which demonstrate that the damages caused to soybean plants by glyphosate are influenced by the cultivar planted, the dose, the formulation of the herbicide utilized, and edaphoclimatic factors before and after the application (SANTOS et al., 2007; ZOBIOLE et al., 2011).

Another fact that is worthy of note from this evaluation is seen in the soybean plants treated only with $\operatorname{Crop}^{+}\left(0.5 \mathrm{~L} \cdot \mathrm{ha}^{-1}\right.$; without any concurrent herbicide treatment), given that such plants exhibited higher SPAD index values than those observed in the check. It is possible that this result originates 
Table 3. The SPAD index of soybean plants subjected to the postemergent application of glyphosate in conjunction with a foliar elicitor product. Rio Verde (Goiás), 2018-2019.

\begin{tabular}{|c|c|c|c|c|c|}
\hline \multirow{3}{*}{ Treatments } & \multirow{3}{*}{ Dose (g or L·ha ${ }^{-1}$ ) } & \multicolumn{4}{|c|}{ SPAD Index } \\
\hline & & \multicolumn{2}{|c|}{7 DAA } & \multicolumn{2}{|c|}{14 DAA } \\
\hline & & Herb. & Check & Herb. & Check \\
\hline Glyphosate & 1296 & 38.9 a & $41.0 \mathrm{a}$ & $40.2 \mathrm{a}$ & $41.6 \mathrm{a}$ \\
\hline Glyphosate + Crop ${ }^{+}$ & $1296+0.25$ & $38.4 \mathrm{a}$ & $40.1 \mathrm{a}$ & $39.9 a$ & $41.2 \mathrm{a}$ \\
\hline 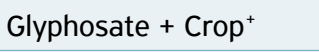 & $1296+0.5$ & $37.7 \mathrm{a}$ & 39.9 a & $40.3 \mathrm{a}$ & $40.9 \mathrm{a}$ \\
\hline Glyphosate & 2592 & $37.0 \mathrm{~b}$ & $40.2 \mathrm{a}$ & $38.7 b$ & $41.6 \mathrm{a}$ \\
\hline Glyphosate + Crop $^{+}$ & $2592+0.25$ & $37.2 \mathrm{~b}$ & $40.2 \mathrm{a}$ & $38.5 b$ & $41.3 \mathrm{a}$ \\
\hline 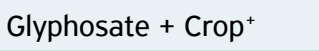 & $2592+0.5$ & $35.3 b$ & $39.4 \mathrm{a}$ & $38.5 b$ & $41.3 \mathrm{a}$ \\
\hline $2 \times$ glyphosate & $2 \times 1296$ & $36.1 \mathrm{~b}$ & $41.2 \mathrm{a}$ & $38.6 b$ & $40.9 a$ \\
\hline $2 \times$ glyphosate + Crop $^{+}$ & $2 \times 1296+0.25$ & $39.1 \mathrm{a}$ & $40.8 \mathrm{a}$ & $40.0 \mathrm{a}$ & $40.3 \mathrm{a}$ \\
\hline $2 \times$ glyphosate + Crop $^{+}$ & $2 \times 1296+0.5$ & $38.0 \mathrm{a}$ & $40.5 \mathrm{a}$ & $38.4 \mathrm{~b}$ & $40.6 \mathrm{a}$ \\
\hline Crop $^{+}$ & 0.5 & 38.8 a & $40.4 \mathrm{a}$ & $40.7 \mathrm{a}$ & $40.8 \mathrm{a}$ \\
\hline CV (\%) & & 4.39 & & 47 & \\
\hline \multirow{2}{*}{ Treatments } & \multirow{2}{*}{ Dose (g or $L \cdot h a^{-1}$ ) } & \multicolumn{2}{|c|}{21 DAA } & \multicolumn{2}{|c|}{35 DAA } \\
\hline & & Herb. & Check & Herb. & Check \\
\hline Glyphosate & 1296 & $41.4 \mathrm{a}$ & $42.2 \mathrm{a}$ & $47.4 \mathrm{a}$ & $48.2 \mathrm{a}$ \\
\hline Glyphosate + Crop $^{+}$ & $1296+0.25$ & $41.5 \mathrm{a}$ & $42.2 \mathrm{a}$ & $44.1 \mathrm{~b}$ & $47.0 \mathrm{a}$ \\
\hline 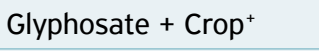 & $1296+0.5$ & $42.9 \mathrm{a}$ & $42.4 \mathrm{a}$ & $48.8 \mathrm{a}$ & $47.4 \mathrm{a}$ \\
\hline Glyphosate & 2592 & $40.3 \mathrm{a}$ & 42.0 a & $45.3 \mathrm{a}$ & $47.0 \mathrm{a}$ \\
\hline Glyphosate + Crop $^{+}$ & $2592+0.25$ & $40.0 \mathrm{~b}$ & $42.8 \mathrm{a}$ & $47.2 \mathrm{a}$ & $48.5 \mathrm{a}$ \\
\hline 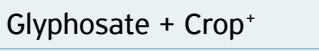 & $2592+0.5$ & $41.7 \mathrm{a}$ & $42.3 \mathrm{a}$ & $43.6 \mathrm{~b}$ & $48.6 \mathrm{a}$ \\
\hline $2 \times$ glyphosate & $2 \times 1296$ & $41.1 \mathrm{a}$ & $41.0 \mathrm{a}$ & $48.1 \mathrm{a}$ & $48.3 a$ \\
\hline $2 \times$ glyphosate + Crop $^{+}$ & $2 \times 1296+0.25$ & $41.0 \mathrm{a}$ & $40.2 \mathrm{a}$ & $46.5 \mathrm{a}$ & $47.4 \mathrm{a}$ \\
\hline $2 \times$ glyphosate + Crop $^{+}$ & $2 \times 1296+0.5$ & $38.7 b$ & $41.0 \mathrm{a}$ & 50.0 a & $47.6 \mathrm{a}$ \\
\hline Crop $^{+}$ & 0.5 & $42.6 \mathrm{a}$ & $41.3 a$ & $52.5 \mathrm{a}$ & $48.1 \mathrm{~b}$ \\
\hline CV (\%) & & \multicolumn{2}{|c|}{3.56} & \multicolumn{2}{|c|}{4.40} \\
\hline
\end{tabular}

DAA = days after application; Herb. = herbicide. ${ }^{*}$ Means followed by different letters are different according to the F-test at $5 \%$ probability.

from the chemical composition of $\mathrm{Crop}^{+}$, which consists of foliar elicitors as well as amino acids and nutrients (sulfur, zinc, iron, manganese, among others; (FMC, 2019).

A study performed with Crop ${ }^{+}$on soybean crops reported an increase in photosynthesis of $16.0 \%$ compared to plants that received no Crop ${ }^{+}$(CYTOZYME, 2019). This provides evidence that the benefit of utilizing $\mathrm{Crop}^{+}$on soybean is not seen merely in the increase of green color in the leaves of the treated plants (SPAD index), but also can be observed as an increase in photosynthesis, which in turn can, occasionally, result in a greater crop yield potential.

In addition, because of the amino acids in its composition, $\mathrm{Crop}^{+}$can reduce the damage caused by glyphosate. ZOBIOLE et al. (2010c) demonstrated that providing amino acids in conjunction with glyphosate, in applications that were performed exogenously, reduced the deleterious effects brought on by the herbicide, especially relating to the crop's rate of photosynthesis.
Soybean is grown in a wide range of plant populations, with the ideal density for each cultivar defined based on research carried out before the commercial launch of the strain from the breeding program. Despite these variations, because of ample phenotypic plasticity, it is sometimes common to observe changes in plant population, without the observation of a direct effect on the crop yield (RAMBO et al., 2003). Nevertheless, in situations in which there is a reduction in the prescribed population, effects on the yield can be seen regardless of whether this decrease in crop stand occurs because of shortcomings in the sowing operation or inadequate management of the crop (CONSTANTIN et al., 2009).

Over the course of the three evaluations, a tendency towards crop stand reduction was found in all of the treatments and checks, which demonstrates the importance of evaluations at both the beginning of soybean plant growth and at the time of harvest, because plant death can occur during the crop cycle (Table 4). Regarding the effect of the treatments on this response variable, the treatment in which 
a difference was observed when compared to its respective control was only the group that consisted of the application of glyphosate + Crop", with the dose of $2592+0.5 \mathrm{~g}$ or L.ha- ${ }^{-1}$.

Plant height is a particularly interesting measurement due its influence on certain parameters of cultivation, such as the potential for lodging in the soybean plant when there is great increase in plant height, or production losses in the mechanized operation of harvest, due to the presence of beans at heights beneath that of the harvest cutting platform. During the three height evaluations, only in the first (14 days after application) has a difference seen between a given treatment and its respective check (Table 5). On that occasion, the soybean plants treated with glyphosate $+\mathrm{Crop}^{+}(2592+0.25 \mathrm{~g}$ or L.ha $\left.{ }^{-1}\right)$ were shorter than their respective checks.

For the mass of 100 grains, there were no differences observed between the treatments and their respective checks, demonstrating that there was no negative effect of the application of glyphosate on grain mass (Table 5). In a study by ALBRECHT et al. (2012), in which the effect of applying herbicides on the quality of soybean seeds was evaluated, it was reported that soybean mass was not influenced by the postemergence of single application of glyphosate. Rather, differences in mass only occurred when the herbicide was combined with chlorimuron.

Crop yield was affected when the sequential application of glyphosate - which in both cases utilized a dose of $1296 \mathrm{~g} \cdot \mathrm{ha}^{-1}$ - occurred, with an observed reduction of $10.58 \%$ (6.81 bags $\left.\cdot \mathrm{ha}^{-1}\right)$ compared to the respective checks. The lack of significant correspondence between the mass of 100 grains and the overall yield for the sequential application treatment could be related to the fact that this treatment affected some other component of crop yield (example: number of beans per plant).

In the treatment using a single application of glyphosate $\left(2592 \mathrm{~g} \cdot \mathrm{ha}^{-1}\right)$, the quantity of active ingredients of glyphosate that soybean had to metabolize was the same as in the treatment that consisted of the sequential application of glyphosate

Table 4. Stand and height of soybean plants subjected to the postemergent application of glyphosate in conjunction with a foliar elicitor product. Rio Verde (Goiás), 2018-2019.

\begin{tabular}{|c|c|c|c|c|c|c|c|}
\hline \multirow{3}{*}{ Treatments } & \multirow{3}{*}{ Dose (g or L·ha ${ }^{-1}$ ) } & \multicolumn{6}{|c|}{ Stand (plants $2 \cdot \mathrm{m}^{-1}$ ) } \\
\hline & & \multicolumn{2}{|c|}{14 DAA } & \multicolumn{2}{|c|}{35 DAA } & \multicolumn{2}{|c|}{ Harvest } \\
\hline & & Herb. & Check & Herb. & Check & Herb. & Check \\
\hline Glyphosate & 1296 & $35.0 \mathrm{a}$ & $32.7 \mathrm{a}$ & $34.0 \mathrm{a}$ & $32.1 \mathrm{a}$ & $32.2 \mathrm{a}$ & $31.5 \mathrm{a}$ \\
\hline Glyphosate + Crop $^{+}$ & $1296+0.25$ & $31.5 a$ & $33.7 \mathrm{a}$ & $30.5 \mathrm{a}$ & $32.8 \mathrm{a}$ & $29.5 \mathrm{a}$ & $31.8 \mathrm{a}$ \\
\hline Glyphosate + Crop $^{+}$ & $1296+0.5$ & $34.7 \mathrm{a}$ & $31.7 \mathrm{a}$ & $33.7 \mathrm{a}$ & 30.8 a & $32.5 \mathrm{a}$ & $29.8 \mathrm{a}$ \\
\hline Glyphosate & 2592 & $29.7 \mathrm{a}$ & $31.1 \mathrm{a}$ & $29.2 \mathrm{a}$ & $30.1 \mathrm{a}$ & $28.2 \mathrm{a}$ & $29.1 \mathrm{a}$ \\
\hline Glyphosate + Crop $^{+}$ & $2592+0.25$ & $31.7 \mathrm{a}$ & $33.3 \mathrm{a}$ & $31.0 \mathrm{a}$ & $32.5 \mathrm{a}$ & $29.7 \mathrm{a}$ & $31.6 \mathrm{a}$ \\
\hline Glyphosate + Crop $^{+}$ & $2592+0.5$ & $35.5 \mathrm{a}$ & $31.0 \mathrm{~b}$ & $34.5 \mathrm{a}$ & $30.1 \mathrm{~b}$ & $33.5 \mathrm{a}$ & $29.1 \mathrm{~b}$ \\
\hline $2 \times$ glyphosate & $2 \times 1296$ & $31.5 a$ & $32.1 \mathrm{a}$ & $30.5 a$ & $31.2 \mathrm{a}$ & $28.5 \mathrm{a}$ & $30.1 \mathrm{a}$ \\
\hline $2 \times$ glyphosate + Crop $^{+}$ & $2 \times 1296+0.25$ & $32.2 \mathrm{a}$ & $32.1 \mathrm{a}$ & $31.5 \mathrm{a}$ & $31.1 \mathrm{a}$ & $29.2 \mathrm{a}$ & $30.0 \mathrm{a}$ \\
\hline 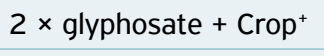 & $2 \times 1296+0.5$ & $31.7 \mathrm{a}$ & $34.1 \mathrm{a}$ & $31.2 \mathrm{a}$ & $33.2 \mathrm{a}$ & $30.2 \mathrm{a}$ & $32.1 \mathrm{a}$ \\
\hline Crop $^{+}$ & 0.5 & $32.5 \mathrm{a}$ & $32.8 \mathrm{a}$ & $31.5 \mathrm{a}$ & $31.8 \mathrm{a}$ & $30.5 a$ & $30.7 \mathrm{a}$ \\
\hline CV (\%) & & & & & & & \\
\hline \multirow{2}{*}{ Treatments } & \multirow{2}{*}{ Dose (g or $L \cdot h a^{-1}$ ) } & \multicolumn{6}{|c|}{ Plant height $(\mathrm{cm})$} \\
\hline & & Herb. & Check & Herb. & Check & Herb. & Check \\
\hline Glyphosate & 1296 & $72.4 \mathrm{a}$ & $72.1 \mathrm{a}$ & $84.9 \mathrm{a}$ & $84.9 a$ & $80.8 \mathrm{a}$ & $81.7 \mathrm{a}$ \\
\hline Glyphosate + Crop ${ }^{+}$ & $1296+0.25$ & $70.6 \mathrm{a}$ & $72.7 \mathrm{a}$ & $86.6 \mathrm{a}$ & $86.3 \mathrm{a}$ & $84.2 \mathrm{a}$ & $82.1 \mathrm{a}$ \\
\hline Glyphosate + Crop ${ }^{+}$ & $1296+0.5$ & $73.5 a$ & $72.8 \mathrm{a}$ & $87.0 \mathrm{a}$ & 86.2 a & $84.0 \mathrm{a}$ & $81.6 \mathrm{a}$ \\
\hline Glyphosate & 2592 & $75.1 \mathrm{a}$ & $73.2 \mathrm{a}$ & $86.4 \mathrm{a}$ & $88.4 \mathrm{a}$ & $83.7 \mathrm{a}$ & $84.3 \mathrm{a}$ \\
\hline Glyphosate + Crop ${ }^{+}$ & $2592+0.25$ & $71.6 b$ & $74.8 \mathrm{a}$ & $85.7 \mathrm{a}$ & 86.6 a & $82.6 \mathrm{a}$ & $84.8 \mathrm{a}$ \\
\hline Glyphosate + Crop ${ }^{+}$ & $2592+0.5$ & $71.7 \mathrm{a}$ & $71.5 \mathrm{a}$ & $86.0 \mathrm{a}$ & $84.2 \mathrm{a}$ & $82.1 \mathrm{a}$ & $80.9 \mathrm{a}$ \\
\hline $2 \times$ glyphosate & $2 \times 1296$ & $72.0 \mathrm{a}$ & $73.3 \mathrm{a}$ & $84.6 \mathrm{a}$ & $83.6 \mathrm{a}$ & $85.2 \mathrm{a}$ & $82.3 \mathrm{a}$ \\
\hline $2 \times$ glyphosate + Crop $^{+}$ & $2 \times 1296+0.25$ & $74.2 \mathrm{a}$ & $74.0 \mathrm{a}$ & $91.1 \mathrm{a}$ & 89.0 a & $84.2 \mathrm{a}$ & $84.1 \mathrm{a}$ \\
\hline $2 \times$ glyphosate + Crop $^{+}$ & $2 \times 1296+0.5$ & $70.3 a$ & $72.7 \mathrm{a}$ & 84.2 a & $86.1 \mathrm{a}$ & 79.6 a & $81.4 \mathrm{a}$ \\
\hline $\mathrm{Crop}^{+}$ & 0.5 & $71.9 a$ & $71.2 \mathrm{a}$ & $87.7 \mathrm{a}$ & $87.9 a$ & $84.6 \mathrm{a}$ & $81.2 \mathrm{a}$ \\
\hline
\end{tabular}

DAA = days after application; Herb. = herbicide. * Means followed by different letters are different according to the F-test at $5 \%$ probability. 
Table 5. Mass of 100 grains and yield of soybean plants after the postemergent application of glyphosate in different doses and stages and in conjunction with Crop ${ }^{+}$. Rio Verde (Goiás), 2018-2019.

\begin{tabular}{|c|c|c|c|c|c|}
\hline \multirow{2}{*}{ Treatments } & \multirow{2}{*}{ Dose (g or $L \cdot h a^{-1}$ ) } & \multicolumn{2}{|c|}{ Mass of 100 grains (g) } & \multicolumn{2}{|c|}{ Yield $\left(\mathbf{k g} \cdot \mathrm{ha}^{-1}\right)$} \\
\hline & & Herb. & Check & Herb. & Check \\
\hline Glyphosate & 1296 & $15.9 \mathrm{a}$ & $16.2 \mathrm{a}$ & $3575.6 \mathrm{a}$ & $3733.4 \mathrm{a}$ \\
\hline Glyphosate + Crop ${ }^{+}$ & $1296+0.25$ & $16.4 \mathrm{a}$ & $16.6 \mathrm{a}$ & $3591.2 \mathrm{a}$ & $3795.4 \mathrm{a}$ \\
\hline Glyphosate + Crop $^{+}$ & $1296+0.5$ & $16.1 \mathrm{a}$ & $16.0 \mathrm{a}$ & $3631.0 \mathrm{a}$ & $3739.0 \mathrm{a}$ \\
\hline Glyphosate & 2592 & $16.6 \mathrm{a}$ & $16.4 \mathrm{a}$ & $3535.8 \mathrm{a}$ & $3752.8 a$ \\
\hline Glyphosate + Crop $^{+}$ & $2592+0.25$ & $16.2 \mathrm{a}$ & $16.0 \mathrm{a}$ & $3604.1 \mathrm{a}$ & $3713.1 \mathrm{a}$ \\
\hline Glyphosate + Crop ${ }^{+}$ & $2592+0.5$ & $16.6 \mathrm{a}$ & $16.4 \mathrm{a}$ & $3783.4 \mathrm{a}$ & $3864.4 \mathrm{a}$ \\
\hline $2 \times$ glyphosate & $2 \times 1296$ & $16.3 \mathrm{a}$ & $16.5 \mathrm{a}$ & $3454.0 \mathrm{~b}$ & $3862.7 \mathrm{a}$ \\
\hline $2 \times$ glyphosate + Crop $^{+}$ & $2 \times 1296+0.25$ & $16.2 \mathrm{a}$ & $16.4 \mathrm{a}$ & $3620.0 \mathrm{a}$ & $3785.0 \mathrm{a}$ \\
\hline $2 \times$ glyphosate + Crop $^{+}$ & $2 \times 1296+0.5$ & $16.4 \mathrm{a}$ & $16.6 \mathrm{a}$ & $3630.9 a$ & $3803.3 \mathrm{a}$ \\
\hline $\mathrm{Crop}^{+}$ & 0.5 & $16.1 \mathrm{a}$ & $16.00 \mathrm{a}$ & $3746.5 \mathrm{a}$ & $3546.2 \mathrm{a}$ \\
\hline CV (\%) & & \multicolumn{2}{|c|}{3.43} & \multicolumn{2}{|c|}{7.81} \\
\hline
\end{tabular}

Herb. $=$ herbicide. ${ }^{*}$ Means followed by different letters are different according to the F-test at $5 \%$ probability.

$\left(1296 / 1296 \mathrm{~g} \cdot \mathrm{ha}^{-1}\right)$. However, differences in yield between the treatment and check were only observed when the application of glyphosate occurred on multiple occasions. This phenomenon can possibly be explained by the fact that the plant had been exposed to a greater period of time in which to metabolize the herbicide, which could ultimately have interfered with crop growth. Other studies have already reported that the sequential application of glyphosate, whether isolated or in conjunction with other herbicides, can cause reductions in crop yield (ALONSO et al., 2010; CONSTANTIN et al., 2016).

Comparing the effect of the treatments wherein glyphosate was applied sequentially, in the same doses in which a reduction of soybean yield was seen but in which application occurred in conjunction with $\mathrm{Crop}^{+}$(sequential glyphosate $+\mathrm{Crop}^{+}$in doses of $1296+0.25$ or $0.5 \mathrm{~g}$ or L-ha $\left.{ }^{-1}\right)$, it is noteworthy that no reductions were observed when compared with their respective checks. This demonstrates that the addition of $\mathrm{Crop}^{+}$to the glyphosate application aided in the reduction of the negative effects of the herbicide on the soybean. As such, no reductions in crop yield were observed.
For the other treatments evaluated, no reductions in crop yield were observed. The volume of precipitation during the period of the experiment could have contributed to the fact that the negative effects of glyphosate on the crop were not as pronounced, given that the maximum period of rain scarcity during the experiment was 6 days (Fig. 1).

\section{CONCLUSIONS}

The use of Crop ${ }^{+}$in soybean plants led to an increase in the SPAD index compared to the control without herbicide application. When Crop ${ }^{+}$was applied in conjunction with glyphosate, it made possible the decrease of visual symptoms of damage, preventing reductions in soybean yield when plants were subjected to sequential application of glyphosate. The beneficial effects brought about by $\mathrm{Crop}^{+}$demonstrate the potential of the product's use in reducing the negative effects of glyphosate.

ACKNOWLEDGEMENTS: Not applicable.

FUNDING: This work did not receive any specific grant from funding agencies in the public, commercial, or not-for-profit sectors.

CONFLICTS OF INTEREST: All authors declare that they have no conflict of interest.

ETHICAL APPROVAL: Not applicable.

AVAILABILITY OF DATA AND MATERIAL: The datasets generated and/or analyzed during the current study are available from the corresponding author on reasonable request.

AUTHORS' CONTRIBUTIONS: Conceptualization: Constantin, J.; Braz, G.B.P.; Oliveira Júnior, R.S. Data curation: Braz, G.B.P.; Andrade, C.L.L.; Pereira, B.C.S. Formal analysis: Braz, G.B.P. Methodology: Constantin, J.; Braz, G.B.P.; Machado, F.G. Supervision: Constantin, J.; Braz, G.B.P.; Oliveira Júnior, R.S. Writing - original draft: Braz, G.B.P.; Machado, F.G. Writing review \& editing: Braz, G.B.P. Oliveira Júnior, R.S.; Machado, F.G. 

REFERENCES

ADEGAS, F.S.; VARGAS, L.; GAZZIERO, D.L.P.; KARAM, D.; SILVA, A.F.; AGOSTINETTO, D. Impacto econômico da resistência de plantas daninhas a herbicidas no Brasil (Circular Técnica 132). Londrina: Embrapa Soja, 2017. 11 p. Available from: https:// ainfo.cnptia.embrapa.br/digital/bitstream/item/162704/1/ CT132-OL.pdf. Access on: 10 Jun. 2019.

ALBRECHT, L.P.; ALONSO, D.G.; ALBRECHT, A.J.P.; OLIVEIRA JÚNIOR., R.S.; BRACCINI, A.L.; CONSTANTIN, J. Glyphosate e associações em pós-emergência no desempenho agronômico e na qualidade das sementes de soja RR ${ }^{\circledR}$. Planta Daninha, Viçosa, v.30, n.1, p.139-146, 2012. https://doi.org/10.1590/ SO $100-83582012000100016$

ALONSO, D.G.; CONSTANTIN, J.; OLIVEIRA JÚNIOR, R.S.; ARANTES, J.G.Z.; CAVALIERI, S.D.; SANTOS, G.; RIOS, F.A.; FRANCHINI, L.H.M. Selectivity of glyphosate tank mixtures for RR soybean. Planta Daninha, Viçosa, v.29, n.4, p.929-937, 2011. https:// doi.org/10.1590/SO100-83582011000400024

ALONSO, D.G.; CONSTANTIN, J.; OLIVEIRA JÚNIOR, R.S.; BIFFE, D.F.; RAIMONDI, M.A.; GEMELLI, A.; BLAINSKI, E.; CARNEIRO, J.C. Selectivity of glyphosate in tank mixtures for RR soybean in sequential applications with mixtures only in the first or second application. Planta Daninha, Viçosa v.28, n.4, p.865-875, 2010. https://doi.org/10.1590/SO100-83582010000400020

BECKIE, H.J.; HALL, L.M. Genetically-modified herbicide-resistant (GMHR) crops a two-edged sword? An Americas perspective on development and effect on weed management. Crop Protection, Lincoln, v.66, p.40-45, 2014. https://doi.org/10.1016/j. cropro.2014.08.014

BRASMAX. Cultivares da Região Cerrado: BRASMAX FLX IPRO. 2019. Available from: http://www.brasmaxgenetica. com.br/cultivar-regiao-cerrado $/$ ?produto $=4864$. Access on: 22 Mar. 2019.

CONSTANTIN, J.; OLIVEIRA JÚNIOR, R.S.; GHENO, E.A.; BIFFE, D.F.; BRAZ, G.B.P.; WEBER, F.; TAKANO, H.K. Prevention of yield losses caused by glyphosate in soybeans with biostimulant. African Journal of Agricultural and Research, Ago-Iwoye, v. 1 1, n. 18, p.1601-1607, 2016. https://doi.org/10.5897/AJAR2016.10809

CONSTANTIN, J.; OLIVEIRA JUNIOR, R.S.; ZOBIOLE, L.H.S.; DALBOSCO, M.; ARANTES, J.G.; ALONSO, D.G. Influência de sistemas de manejo sobre o desenvolvimento e a produtividade da soja. Revista Ceres, Viçosa, v.56, n.3, p.274-282, 2009.

CYTOZYME. How does Cytozyme reduce the effects of abiotic stress? 2019. Available from: https://cytozymeag.com/stressreduction. Access on: 22 Mar. 2019.

EMPRESA BRASILEIRA DE PESQUISA AGROPECUÁRIA (EMBRAPA). Tecnologias de produção de soja - Região Central do Brasil 2011 (Sistemas de Produção 14). Londrina: Embrapa Soja, 2010. 247p. Available from: https://ainfo.cnptia.embrapa.br/digital/ bitstream/item/23225/1/Sistema-Producao 14-VE.pdf. Access on: 25 Apr. 2019.
FERREIRA, D.F. Sisvar: a computer statistical analysis system. Ciência e Agrotecnologia, Lavras, v.35, n.6, p.1039-1042, 2011. https://doi.org/10.1590/S1413-70542011000600001

FMC. Fertís FMC: Crop $^{+}$. 2019. Available from: https://www. fmcagricola.com.br/Produtos/DetalhesProdutos/22. Access on: 23 Mar. 2019.

GIL, P.T.; FONTES, P.C.R.; CECON, P.R.; FERREIRA, F.A. Índice SPAD para o diagnóstico do estado de nitrogênio e para o prognóstico da produtividade da batata. Horticultura Brasileira, Brasília, v.20, n.4, p.61 1-615, 2002. https://doi.org/10.1590/ S0102-05362002000400020

GREEN, J.M. The rise and future of glyphosate and glyphosateresistant crops. Pest Management Science, Oxford, v.74, n.5, p.1035-1039, 2018. https://doi.org/10.1002/ps.4462

INTERNATIONAL HERBICIDE-RESISTANT WEED DATABASE (HEAP). International survey of herbicide resistant weeds. 2019. Available from: http://www.weedscience.org/Pages/filter.aspx. Access on: 23 Mar. 2019.

KRENCHINSKI, F.H., ALBRECHT, L.P., ALBRECHT, A.J.P., CESCO, V.J.S., RODRIGUES, D.M., PORTZ, R.L., ZOBIOLE, L.H.S. Glyphosate affects chlorophyll, photosynthesis and water use of four Intacta RR, soybean cultivars. Acta Physiologiae Plantarum, Poznan, v.39, n.2, p.63, 2017. https://doi.org/10.1007/ s1 1738-017-2358-0

MACHADO, F.G.; MENEZES, C.C.E.; CAMPOS, G.W.B.; TAKANO, H.K.; OLIVEIRA JÚNIOR, R.S.; BRAZ, G.B.P. Development and grain quality of soybean cultivars treated with pyraclostrobin and biostimulant. Comunicata Scientiae, Bom Jesus, v.9, n.2, p.235-241, 2018. https://doi.org/10.14295/cs.v9i2.2072

MATYSIAK, K.; MIZINIAK, W.; KACZMAREK, S.; KIERZEK, R. Herbicides with natural and synthetic biostimulants in spring wheat. Ciência Rural, Santa Maria, v.48, n.11, p.e20180405, 2018. https://doi.org/10.1590/0103-8478cr20180405

OVEJERO, R.F.L.; TAKANO, H.K.; NICOLAI, M.; FERRREIRA, A.; MELO, M.S.C.; CAVENAGHI, A.L.; CHRISTOFFOLETI, P.J.; OLIVEIRA JÚNIOR, R.S. Frequency and dispersal of glyphosateresistant sourgrass (Digitaria insularis) populations across Brazilian agricultural production areas. Weed Science, Georgia, v.65, n.2, p.285-294, 2017. https://doi.org/10.1017/ wsc. 2016.31

RAMBO, L.; COSTA, J.A.; PIRES, J.L.F.; PARCIANELLO, G.; FERREIRA, F.G. Rendimento de grãos da soja em função do arranjo de plantas. Ciência Rural, Santa Maria, v.33, n.3, p.405-41 1, 2003. https:// doi.org/10.1590/SO103-84782003000300003

SANTOS, J.B.; FERREIRA, E.A.; REIS, M.R.; SILVA, A.A.; FIALHO, C.M.T.; FREITA, M.A.M. Avaliação de formulações de glyphosate sobre soja Roundup Ready. Planta Daninha, Viçosa, v.25, n.1, p.165-171, 2007. https://doi.org/10.1590/ So $100-83582007000100018$ 
SANTOS, V.M.; MELO, A.V.; CARDOSO, D.P.; SILVA, Á.R.; BENÍCIO, L.P.F.; FERREIRA, E.A. Desenvolvimento de plantas de soja em função de bioestimulantes em condições de adubação fosfatada. Bioscience Journal, Uberlândia, v.30, n.4, p.1087-1094, 2014. Available from: http://www.seer.ufu. $\mathrm{br} /$ index.php/biosciencejournal/article/view/18184. Access on: 11 Apr. 2019.

SERRA, A.P.; MARCHETTI, M.E.; CANDIDO, A.C.S.; DIAS, A.C.R.; CHRISTOFFOLETI, P.J. Influência do glifosato na eficiência nutricional do nitrogênio, manganês, ferro, cobre e zinco em soja resistente ao glifosato. Ciência Rural, Santa Maria, v.41, n.1, p.77-84, 2011 . https://doi.org/10.1590/ so $103-84782011000100013$

ZOBIOLE, L.H.S.; KREMER, R.J.; OLIVEIRA JÚNIOR, R.S.; CONSTANTIN, J. Glyphosate affects chlorophyll, nodulation and nutrient accumulation of "second generation" glyphosate-resistant soybean (Glycine max L.). Pesticide Biochemistry and Physiology, Amherst, v.99, n. 1, p.53-60, 2011 . https://doi.org/10.1016/j. pestbp.2010.10.005
ZOBIOLE, L.H.S.; KREMER, R.J.; OLIVEIRA JÚNIOR, R.S.; CONSTANTIN, J. Glyphosate effects on photosynthesis, nutrient accumulation and nodulation in glyphosate-resistant soybean. Journal of Plant Nutrition and Soil Science, Weinheim, v. 175, n.2, p.319-330, 2012. https://doi.org/10.1002/jpln.201000434

ZOBIOLE, L.H.S.; OLIVEIRA JÚNIOR, R.S.; CONSTANTIN, J.; BIFFE, D.F.; KREMER, R.J. Uso de aminoácido exógeno na prevenção de injúrias causadas por glyphosate na soja RR. Planta Daninha, Viçosa, v.28, n.3, p.643-653, 2010c. https://doi.org/10.1590/ S0100-83582010000300022

ZOBIOLE, L.H.S.; OLIVEIRA JUNIOR, R.S.; KREMER, R.J.; CONSTANTIN, J.; YAMADA, T.; CASTRO, C.; OLIVEIRA, F.A.; OLIVEIRA JÚNIOR, A. Effect of glyphosate on symbiotic $\mathrm{N}_{2}$ fixation and nickel concentration in glyphosate-resistant soybeans. Applied SoilEcology, Innsbruck, v.44, n.2, p.176-180, 2010b.https://doi.org/10.1016/j.apsoil.2009.12.003

ZOBIOLE, L.H.S.; OLIVEIRA JÚNIOR, R.S.; KREMER, R.J.; CONSTANTIN, J.; BONATO, C.M.; MUNIZ, A.S. Water use efficiency and photosynthesis of glyphosate-resistant soybean as affected by glyphosate. Pesticide Biochemistry and Physiology, Amherst, v.97, n.3, p. 182-193, 2010 a. https://doi.org/10.1016/j.pestbp.2010.01.004 